\title{
Consensus and Power in Deliberative Democracy
}

\section{TIM HEYSSE}

Katholieke Universiteit Brussel, Belgium

(Received 3 March 2005)

\begin{abstract}
How does public discussion contribute to the reasonableness with which power is exercised in a democracy? Contemporary answers to this question (such as formulated by Rawls or Habermas), are often based upon two interconnected preconceptions. These are, 1. the idea that the value of public discussion lies primarily in the fact that citizens can reach a reasonable consensus through argumentation and discussion and, 2. the belief that the exercise of power is legitimate only if it is determined by a reasonable consensus among citizens. In this sense, 'reasonable consensus among citizens' eliminates, under ideal conditions, the 'autonomy' of the exercise of power. However, these ideals of democracy appear to conflict with certain aspects of democratic society; aspects, moreover, which we tend to value quite highly. I therefore advance an alternative account of the reasonableness of power in democratic societies; one which acknowledges both the characteristically unlimited scope of public discussion in democratic society and the fact that such discussion rarely or perhaps even never ends in a general consensus. In order to elucidate the democratic character of society we must explain the relationship between discussion and power in such a way that we understand both the need for discussion and the necessity of an autonomous exercise of power.
\end{abstract}

"Under conditions of representative government", Hannah Arendt writes, "the people are supposed to rule those who govern them". ${ }^{1}$ The meaning of this phrase may not be immediately entirely clear, as is often the case with such platitudes. Nevertheless, it is instructive for three reasons. Firstly, by explicitly referring to "ruling" and "governing", Arendt leaves no room for doubt concerning the fact that, in the words of John Rawls, even in democratic societies, "the fundamental relation of citizenship includes among other things the relation between free and equal citizens who exercise

Correspondence Address: Tim Heysse, Katholieke Universiteit Brussel/Vlaams Parlement, Vrijheidslaan 17, B-1081 Brussel-Koekelberg, Belgium. Email: Tim.Heysse@kubrussel.ac.be

0020-174X Print/1502-3923 Online/06/030265-25 (C) 2006 Taylor \& Francis

DOI: $10.1080 / 00201740600725723$ 
ultimate political power as a collective body". ${ }^{2}$ Secondly, by distinguishing between "the people who rule" and "those who govern", Arendt suggests that the citizens in a democracy cannot or ought not to take power into their own hands directly. In order to understand what it means to be a citizen in a contemporary democratic society - one formulation of this essay's aim - we must therefore study not only the mutual relations between citizens, but also the relationship between the citizens and those who exercise power. Thirdly, since in a democracy the people are supposed to rule, political power in a democracy is ultimately supposed to be "the power of the public, that is the power of free and equal citizens as a collective body" as Rawls puts it - quite rightly replacing the chimerical notion of 'the people' with the legal notion of 'the citizens'. ${ }^{3}$ (Talking about what is supposed to happen in a democracy, Arendt also indicates that these features of a democracy are not always (fully) realized in every regime that calls itself democratic.)

In this paper, I will not try to clarify Arendt's phrase or examine what particular institutional arrangements it calls for. Returning instead to the recurrent philosophers' dream of democracy as the rule of reason, I shall investigate whether these three features of a democratic political regime suggest an interesting interpretation of public reason. Close attention will be paid to the role of public argumentation and discussion. For, if power is ultimately supposed to be the power of the citizens considered as free and equal, the legitimate and therefore stable exercise of power in a democracy presupposes that the general structure of political authority and (at least a great number of) the actual political decisions and actions "are justified by reasons which are acceptable to many citizens" (Ibid.). Is it not, furthermore, precisely in and through public argumentation and discussion that such reasons may be discovered?

The purpose of this essay is therefore to explain the relationship between public argumentation and discussion and political power in a democracy, how political power can acquire a form of reasonableness in and through this relationship and what sense of 'reasonableness' is meant here. The suggestion is that the term 'democracy' refers to specific conditions or rules for the conquest and exercise of power that, in turn, serve to create a particular balance of power conferring a form of reasonableness on the exercise of power.

The role of argumentation and discussion in democratic politics has received a great deal of attention from contemporary writers in political philosophy (often identified by the general label of 'deliberative democracy'). However, I intend to focus on the interpretations of public reason that have been presented by John Rawls and Jürgen Habermas. Rawls and Habermas are not only the most influential political philosophers of the moment, but their interpretations may also be considered as the extremes of a spectrum in which the different interpretations of public reason (proposed under the label of deliberative democracy) may be arranged. 
Taking their respective criticisms of each other's interpretations as a starting point (sections 1 and 2), I will identify a common difficulty (section 3) and suggest an alternative account of public reasonableness based upon an understanding of communicative power that is not equivalent to the understanding of that notion as presented by Habermas or Arendt (section 4). Although the terms of reference of this paper were originally intended to cover the case of a representative democracy where power is surrendered to elected officials, I will briefly explain why this account may also apply to more direct forms of democracy.

Before discussing the interpretations of public reasonableness presented by Rawls and Habermas, I will first mention an opposing view, if only in order to set it aside and move on. This is the notion of strategic rationality as analysed by rational choice theory. According to the latter, it is rational to choose, among the options available, the particular option that realises the agent's desires or preferences optimally, taking into account the options that other agents involved in the interaction are likely to choose. The positions I have summarily labelled 'deliberative' democracy appear to share as a defining characteristic the claim that rational choice theory cannot provide us with a realistic model of public reason. ${ }^{4}$ For it rests on the assumption that the set of agents, the set of alternatives and the set of preferences are given and not subject to change in the course of the political process. ${ }^{5}$ In contrast to this, public reason demands, it is claimed, that citizens are willing to argue about preferences or alternatives and to transform them if necessary. Mere aggregation of given preferences is not enough.

In what follows, I will assume that this criticism of rational choice theory as an interpretation of public reasonableness is well founded. ${ }^{6}$ Nevertheless, the following theoretical point is worth keeping in mind. As is well known, the exercise of political power may offer a way out of certain coordination problems called "prisoners' dilemmas". These are situations in which no cooperation takes place, because every agent fears that others will take advantage of his or her willingness to cooperate. However, if there is a body that has the power to enforce cooperation, thereby removing the fear of opportunism, cooperation is a rational choice that will, as a rule, be adopted. The exercise of power achieves a more attractive outcome than that which would have been achieved without the use of power. We may therefore say that the exercise of power is, from the point of view of the agents concerned, rational, in the sense that it is rational for them to obey. The exercise of power is an expression of their strategic rationality.

The point worth noting is that this rational exercise of power is only possible if those holding power can maintain a certain distance or autonomy from the individual agents. For although it is rational to choose the cooperative option, rational agents must nevertheless be forced to 
cooperate, as is obvious from the fact that it remains rational to deviate unilaterally from the cooperative option, provided agents can do so with impunity. The rationality of power (as characterized in the previous paragraph) has an air of paradox about it, for even though agents acknowledge that the exercise of power is rationally acceptable to them, it may also be rational to deviate from the option enforced by this rational political power. $^{7}$

\section{Overlapping consensus}

John Rawls' interpretation of public reason is mainly expressed in his second major book, Political Liberalism. Its aim is to explain how the principles of a just and democratic society, formulated in Rawls' 1971 classic, A Theory of Justice, may be realized in our own contemporary society. According to Rawls, the political culture of contemporary democratic society is characterized by what he has labelled 'the fact of (reasonable) pluralism' and 'the fact of oppression'. These expressions refer to the fact that "the diversity of...religious, philosophical and moral doctrines found in modern democratic societies is not a mere historical condition that may soon pass away. It is a permanent historical condition". The only way to suppress this diversity of what Rawls calls 'comprehensive' doctrines is "by oppressive use of state power" ${ }^{8}$ Given these conditions the most reasonable basis for social unity is, according to Rawls, a "political conception of justice" that regulates the basic structure of society and becomes the focus of "an overlapping consensus". To the extent that the political decisions of those in power are intended to put this political conception into practice - a conception upon which citizens have attained an overlapping consensus - the exercise of power may be called reasonable. Hence, reasonable citizens can reasonably be expected to endorse the exercise of power. ${ }^{9}$

Attention is not given here to the content of the political conception about which an overlapping consensus may arise, ${ }^{10}$ but to the very idea of an overlapping consensus and to the interpretation of public reason that this idea entails. The overlapping consensus has two, seemingly incompatible characteristics. On the one hand, Rawls insists that an overlapping consensus must not be taken for a modus vivendi, nor for a constitutional consensus, which only establishes democratic electoral procedures for moderating political rivalry and struggle within society. An overlapping consensus focuses on a conception of justice with which the citizens agree for moral reasons. ${ }^{11}$ On the other hand, the consensus is, as the word itself makes clear, a mere overlapping consensus. The political conception about which an overlapping consensus arises, is not necessarily grounded in shared reasons: "public justification happens when all the reasonable members of political society carry out a justification of the shared 
political conception by embedding it in their several reasonable comprehensive views". ${ }^{12}$

What's more, public reason demands that we abstain from forming an opinion or at any rate from expressing such an opinion publicly about the arguments put forward by proponents of alternative comprehensive doctrines. (These restrictions are part of what Rawls has called "the limits of public reason" and - in earlier papers - "the method of avoidance of controversy": "Citizens do not look into the content of others' doctrines, and so remain within the bounds of the political. Rather, they take into account and give some weight to only the fact - the existence - of the...overlapping consensus itself ". ${ }^{13}$ )

It will be obvious that, in Rawls' political philosophy, public discussion and argumentation do not contribute to establishing consensus. "Public" justification "happens" when certain common political principles can be identified. In order to determine whether or not this is the case, we do not even have to talk to supporters of doctrines different from our own. We can find out by other means, such as referendums or surveys. Of course, once an overlapping consensus concerning a conception of justice is established, this conception may form a public basis for political discussion (for example, about how to apply the conception in particular cases or in novel situations). But consensus is only the basis for public political discussion, not its result. The reason for this lack of appreciation for public argumentation and discussion is quite simple: Rawls does not believe that public argumentation and discussion will lead to consensus, to a common basis for social life. Quite the contrary, argumentation and discussion will only lead to more discussion; it will only lead to endless controversy and therefore does not solve the problem of social unity and stability.

Many critics of Rawls' political philosophy have argued that an interpretation of public reason which attaches only minor importance to public argumentation and discussion goes against our most basic understanding of social life in a democracy. Every plausible interpretation of our contemporary democratic society must take into consideration the fact that "people continue to debate moral questions with reasons they take to be compelling.... They engage in moral discourses in everyday life as well as in politics, most especially disputes concerning constitutional principles". ${ }^{14}$ Rawls cannot deny the political philosophical import of this empirical fact, ${ }^{15}$ since it challenges the very idea of an overlapping consensus. It demonstrates that citizens are willing to criticize each other's reasons for agreeing with a given conception of justice, thereby jeopardizing the overlapping consensus and initiating controversies and discussions that may or may not lead to consensus. Rawls must therefore explain why he is unwilling to take into account the fact that citizens argue about moral questions, whereas he is emphatic that we should do this in the case of the fact of pluralism and the fact of oppression. 
Moreover, if Rawls is simultaneously trying to argue that the political conception about which an overlapping consensus exists is a conception of justice and that it nevertheless should not be the subject of public discussion, his position may be inconsistent. For the following epistemological principle, called 'the convergence commitment' by John Skorupski, ${ }^{16}$ seems plausible: if I believe myself to have good arguments for a particular judgment (for instance concerning the moral justification of a certain conception of justice) these arguments must be good enough for others. Consequently, I must believe that either those others will (ultimately) come to agree with my judgment or their judgment is flawed (i.e. misinformed, prejudiced, incompetent, etc.). If Rawls persists in equating any given political conception with a moral conception of justice - limited to the political, it is true - but with which citizens agree for moral reasons, thereby creating a social structure which can be called fair or just, he cannot consistently ask the same reasonable citizens to refrain from publicly criticizing and discussing the justification advanced in favor of that political conception.

Both this epistemological objection and the general epistemological principle on which it is founded, have direct practical bearing on the relationship implied by the notion of citizenship. For the commitments to argument and discussion that follow from the ideal of consensus are not unconditional: if I have reasons to doubt the judgment of certain others, we may consistently ignore the fact that they object to our (moral) judgments, while continuing to view these judgments as justified. But this does not apply when the objections come from a fellow citizen. To recognize somebody as a fellow citizen, is, at least on Rawls' own conception, to recognize him as a reasonable being, whose general judgment on political issues cannot be faulted as misinformed or prejudiced or incompetent: "In order to fulfill their political role, citizens are viewed as having the intellectual and moral powers appropriate to that role, such as a capacity for a sense of political justice". ${ }^{17}$ Where political issues are at stake, we cannot ignore the objections or criticism of other citizens. ${ }^{18}$

What Rawls does not seem to appreciate sufficiently is the fact that to examine, criticize and discuss arguments may be a mark of respect for the person who has proposed them. If, in adopting Rawls' limits of public reason, we refrain from judging the statements and arguments forwarded by supporters of a doctrine different from our own, we may be able to recognize the validity of some of these arguments seen from the perspective of their supporters - relative to their particular religious, moral or philosophical doctrine. In this sense we acknowledge that the supporters of different doctrines have the right to form their own opinion concerning the moral principles of our society on the basis of whatever (reasonable) doctrine they happen to support. However, we are not able to view their political conception of justice - and their arguments in support of it - as 
claims to (moral) truth that may demand our judgment. ${ }^{19}$ Consequently, we do not view supporters of other doctrines as persons with the capacity to reach a sound judgment regarding a political conception of justice.

In short, Rawls' interpretation of public reasonableness appears to imply that citizens adopt the 'objective' or objectifying attitude of an observer towards fellow citizens supporting a different comprehensive doctrine. However, in adopting such an objective attitude (as opposed to a 'reactive' attitude in the sense of Strawson or a 'performative' attitude in the sense of Habermas), we bracket the reasonableness of the other rather than presuppose it (for instance, we do not even consider the truth or validity of what is said, but attempt rather to merely explain it as, say, a rationalization of fear). This suggests that public reasonableness is, on Rawls' interpretation, a form of strategic rationality: as citizens in pluralistic societies, we have to live with others who have a profoundly different view on life; and as reasonable citizens, endowed with a sense of moral justice, our only aim is to coordinate our social life with citizens supporting a different view on life in a way that we find morally acceptable. ${ }^{20}$ This form of strategic rationality is qualified only by the fact that citizens happen to share certain moral values (as embodied in the political conception that is the focus of an overlapping consensus); a fact which allows them to lead a social life in conformity with their moral beliefs. Certain values may be shared, but the respective citizens' evaluation is both different and indifferent to that of proponents of differing philosophical, moral and religious doctrines.

\section{Communicative power}

Any plausible interpretation of the reasonableness of power and of public reason in a democracy must acknowledge the importance of public argumentation and discussion in an overall vision of political and social life. As is well known, such an interpretation has been proposed by Jürgen Habermas. To summarize Habermas' "discourse theory of law and democracy" in one phrase: its main aim is to explain the 'Janus-face' of a constitutional and democratic state. On the one hand, even a constitutional and democratic state presupposes coercion. On the other hand, the democratic constitution of this corrective state also guarantees that the laws and orders being enforced are established through democratic procedures. Habermas allows that rational citizens may resort to political bargaining and compromises. But in those cases the restriction applies that the outcomes of bargaining and compromising must not be contrary to the fundamental moral norms and ethical values agreed upon by all citizens. Moreover, compromises as Habermas understands the term, imply an agreement about what is fair, even if the parties to the compromise agree to it for different reasons. ${ }^{21}$ We may therefore say that in his interpretation of democratic power the citizens have (in principle) agreed after debate to the 
fundamental decisions (in particular legislation) enforced by those in power. What's more, these debates are held according to procedures justifying the expectation that "the political process leads to rational outcomes". In order to explain the meaning of this notion of public reasonableness and the role of argumentation and discussion in establishing this reasonable exercise of power, Habermas distinguishes between 'administratively employed' power - the sanctioning, organizing, and executive power of the state and its servants that is necessary to enforce decisions on the one hand - and 'communicatively generated' power - the kind of power that is created in and through communication or free and fair deliberation on the other. Communicative power comes into existence when opinions gain approval in 'the process of opinion- and will-formation', as Habermas calls it; a process which takes place in the political public sphere and in parliament. In appropriating, from Arendt, the term communicative power, Habermas wishes to indicate that the state as the apparatus of public administration can be forced to some extent to execute and enforce the decisions agreed upon during public discussion.

While for Rawls unlimited discussion is only a source of unending controversy, Habermas believes that argumentative discussion is particularly effective in eliminating special interests and idiosyncratic opinions, in reconciling opposing views, values and interests and in motivating citizens to abide by agreements reached. Political discussion actually contributes to the stability of society. Furthermore, to the extent that the exercise of administrative power is subordinate to communicative power and consequently executes the decisions agreed upon during public discussion, it may be called 'reasonable'. In general, therefore, the reasonableness of political power - administrative or communicative power - derives from the consensus among citizens generated through public deliberation.

What's more, human rights and democratic principles are, according to Habermas, nothing but the legal translations of rules of reasonable discussion. These rules are assumed to neutralize all undue influence: before "taking the floor" in the public sphere, those who hold (political, social or economic) power must, as it were, lay it down. Hence, other speakers may rule out all strategic considerations. Consequently, insincere rhetoric, manipulation, deception and the silencing of certain speakers are all to be excluded from a democratic public sphere, in its ideal conception. If, furthermore, starting out from different positions, citizens finally reach agreement after a free and fair debate in which the different opinions and arguments have been unequivocally questioned and criticized, such an agreement may be considered an indication of the truth of the conclusion. So when citizens, 'respected as free and equal' agree after discussion on the moral rectitude of a conception of justice for a democratic society, then that consensus is a (defeasible) indication that the conception's principles are indeed morally right, true principles of a just society (i.e. true in a sense 
more or less analogous to the manner in which we predicate empirical statements or scientific theories). In other words, in the public sphere of an (ideal) democracy, a cooperative search for truth takes place and the exercise of power is legitimate from a democratic point of view only if it is aimed at executing the results of this search for truth.

Much that has already been said against Habermas' theory of rational discussion need not be repeated for the purpose of this essay. ${ }^{22}$ With regard to the interpretation of political reasonableness, it is sufficient to refer to those facts of contemporary society Rawls elects to call "the fact of reasonable pluralism" and "the fact of repression". Within the time span that is politically relevant, "conflicts always...remain and limit the extent of possible agreement". ${ }^{23}$ What is more, Rawls rightly emphasizes that the existence of disagreements and pluralism in contemporary society is not a deficiency that would disappear in an ideal democracy. On the contrary, they are part of what makes our societies democratic and, moreover, precisely what we value in our societies: "This pluralism is not seen as a disaster but rather as the natural outcome of the activities of human reason under enduring free institutions. To see reasonable pluralism as a disaster is to see the exercise of reason under the conditions of freedom itself as a disaster". ${ }^{24}$ If Habermas represents disagreement as a shortcoming and looks to an ideal democracy without disagreement, he does not quite understand that which makes our societies democratic.

To be sure, this account only considers one half of Habermas' sociology of contemporary democratic states, disregarding his quite interesting systems-theoretic approach. He readily acknowledges that contemporary societies are just too complex to be governed through deliberation among citizens; that is the reason why we cannot but rely on systems specialized in government through administrative power, such as the bureaucratic state. One of the merits of Habermas' interpretation of democracy is indeed the fact that he explicitly analyses the notions of power and authority or force (Gewalt). This suggests that power, coercion and even force are inevitable aspects of even the most democratic of societies. That insight, however, is spoiled by the emphasis on consensus in his analysis of communicative power. ${ }^{25}$ If decisions are freely made by consensus, what need is there for a state apparatus with the administrative power to enforce them? The use of coercion is an indication that, from a democratic point of view, something went wrong (perhaps unavoidably so), that a rational consensus is not always possible or that citizens are not always reasonable enough to abide by reasonable decisions. In Habermas' interpretation of democracy, administrative power and coercion are defects of actually existing democratic societies, both of which would disappear in an ideal democracy. However, if this is so, then the meaning of the expression, 'communicative power' is uncertain. For in Habermas' interpretation it acquires its meaning in opposition to 'administrative power', since Habermas uses the 
expression to indicate that the state apparatus and those with administrative power can be forced to execute the decisions reached in the public sphere. Ultimately, the origin of both kinds of political power is to be located in the gap between the ideal democracy, on the one hand (including ideal consensus and perfectly reasonable discussions without the interference of power relations) and the actual situation of contemporary society, on the other.

\section{Power without consensus}

The basic difference between Rawls' and Habermas' interpretations is now clear, I hope: while Habermas is confident that public argumentation and discussion will lead to a consensus that "justifies" (through the interaction between communicative and administrative power) "the expectation that the exercise of power in a democracy is reasonable", Rawls believes that argumentation and discussion within the public and political forum (as opposed to confrontations between comprehensive doctrines within the private sphere or within the associations of civil society) endanger that consensus, thereby not only making the reasonable justification of power more problematic, but also jeopardizing the very stability of society. It is, in this case, only an overlapping consensus that can be reasonably expected.

As a result of these divergent expectations with regard to public argumentation and discussion, Rawls and Habermas also propose different interpretations of the kind of public reasonableness expressed in a consensus among citizens. On Habermas' view, consensus, resulting from 'a cooperative search for truth', is the consequence of 'communicative rationality', an epistemic notion of reasonableness linked to our desire to have true beliefs, including true (or 'correct') moral beliefs. In Rawls' political philosophy, however, an overlapping consensus is intended to secure a foundation for social life that is morally acceptable to people who may not necessarily expect to agree on many other vital issues. Rawls' notion of 'public reason' therefore refers to a strategic form of reasonableness tempered by a moral sense of justice.

The views of Rawls and Habermas provide a sort of framework for other contemporary interpretations of public reasonableness falling under the general label of deliberative democracy. As a matter of fact, I believe that it is possible to order these interpretations according to the extent to which they share Habermas' confidence in the political possibilities of discussion and argumentation or, contrarily, are rather more inclined to share Rawls' misgivings. ${ }^{26}$ Although it would be interesting to study these interpretations in detail, this is not the aim of this essay. For, more important than these details, is the fact that both interpretations go against certain uncontroversial facts about democracy. Accordingly, I want to argue that they share certain problematic assumptions. 
However different their interpretations of public reason may be, Rawls and Habermas accept the same general idea about what constitutes the reasonable exercise of power. This idea is that the exercise of power is legitimate only if we are able to show in advance, and on the basis of independent criteria, that a political decision is reasonably acceptable to the citizens. In all other cases, the relations in the polity are nothing but relationships of brute power. ${ }^{27}$ In Rawls' interpretation, the exercise of power is reasonable, if we can show that it is subjected to certain political principles upon which there exists overlapping consensus among citizens. According to Habermas, power is reasonable if it aims to put into practice the decisions on which citizens have reached consensus after reasonable discussion. In both cases the exercise of power is deemed legitimate, if it is somehow sanctioned by an existing consensus. In this sense, coercion is, in principle, unnecessary in a democratic polity. Let us call this general idea about the reasonableness of power in a democracy 'the purely consensual view'.

It may be argued, however, that this purely consensual view distorts the interpretation of the reasonableness of political power proposed by Rawls, Habermas and other supporters of deliberative democracy. Indeed, no political philosopher denies that decisions not sanctioned by a consensus are sometimes imposed upon citizens of a democratic society. ${ }^{28}$ According to Rawls, the political conception of justice upon which an overlapping consensus should arise, is thought to deal only with constitutional essentials and basic justice; other decisions are the consequences of existing power relations. Habermas allows that rational citizens may resort to political bargaining and compromises (with regard to issues where no moral norms or ethical values are at stake). Others point out that certain issues may be settled through adjudication by an external authority. In short, according to this subtler and therefore more plausible view, we must acknowledge that, even in a democracy, political power is more than a matter of putting into practice what was agreed upon by the citizens.

But is this more qualified view essentially different from the purely consensual view? For if these cases of autonomous exercise of power are not simply glossed over as exceptional (but perhaps unavoidable) departures from the ideal of democratic government, the reasonableness of this 'autonomous' exercise of power is usually explained by introducing a kind of 'second-order' consensus. Indeed, it is often assumed that the exercise of power, although not directly sanctioned by consensus, is legitimate only if subjected to certain (mostly moral) norms and procedures upon which a general agreement among citizens does exist. For example, Rawls argues that it is reasonable for citizens to submit to decisions provided that they do not jeopardize the basic structure that is supported by an overlapping consensus among reasonable comprehensive doctrines and is therefore assumed to be just. ${ }^{29}$ In Habermas' view, compromises resulting from 
political bargaining are only acceptable, from a democratic point of view, if they are not contrary to generally accepted norms of which Habermas has presented a formal pragmatic reconstruction and which are supposed to be translated into the constitution and statutes after democratic deliberation. ${ }^{30}$ The very authority of an adjudicator, as Gerald Gaus points out, presupposes that the citizens at least agree on the justifiability of his position (and hence also his competence and impartiality) and on certain shared rules and concepts on which its rulings are based. ${ }^{31}$

Without underestimating in any way the crucial importance of moral norms, formal procedures and fundamental human rights, I want to argue that this 'two-order' interpretation does not lead to an acceptable account of the reasonableness of political power in a democracy. My first two objections are intended to cast doubt on the theoretical usefulness of what I have called the 'second-order consensus', while the third objection is aimed at the supremacy of consensus (whether 'first-order' or 'second-order') in any view attempting to explain the reasonableness of political power by linking it to consensus. It can therefore be applied against the purely consensual view as well.

Firstly, the fact that those in power owe their legitimacy to certain norms and procedures for which there is a second-order consensus among citizens, does not lead to a complete account of the reasonableness of democratic power. For we obviously still have no independent explanation of the reasons citizens have for accepting decisions. ${ }^{32}$ Of course, we can always say - and at some moment of acute political crisis it is worth repeating - that it may be reasonable to submit to the decision. (Continuing the conflict may be even less attractive; as Hobbes would have put it, all citizens have an interest in securing the conditions "of peace and commodious living".) However, merely mentioning the impossibility of postponing a decision and the consequent necessity or even (strategic) rationality of submitting to it entirely omits from such an account the content of the decision and, even more importantly, the role of public argumentation and discussion with regard to that content. Something appears to be missing, as is becoming increasingly clear, if we contrast this account with the case of the imposition of a cooperative option within a prisoner's dilemma. Although the exercise of power is autonomous in a prisoner's dilemma (in the sense that the outcome imposed is not the agent's most favoured option), there is something to be said in favour of the option that is imposed (since it is more favourable than an outcome in which no cooperation takes place). In the second order interpretation it seems to be almost immaterial what the actual decision is that succeeds in resolving the conflict dividing society.

There is no denying the fact that we may as a rule distinguish between the level of everyday political conflicts and the level of the basic structure and constitutional essentials upon which citizens may be agreed. However, my second objection is that philosophers are perhaps too apt to emphasize this 
distinction, thereby ignoring the continuity between the two levels of politics. The fact of the matter is that our submission to particular decisions is a continuation of our support for the norms and procedures to which the decisions and those imposing them owe their legitimacy. ${ }^{33}$ Because of this continuity, support for the norms and procedures may be affected by any (negative) judgment concerning the decisions imposed in compliance with these norms and procedures. Nobody will accept an institutional arrangement that is certain to lead to defeat on all important political issues. ${ }^{34}$ Conversely, the actual content of the basic structure and of constitutional principles are not solely established after fundamental decisions on matters of principle: their specific impact on the lives of individual persons are as (if not more) definitively determined by very routine government decisions, such as decisions with regard to the level of social security benefits.

Incidentally, if we pay sufficient attention to the effects of everyday political conflict on the actual content of the basic structure and on the constitution, we arrive at a more plausible interpretation of the history of democratic societies. We interpret this all too readily as a history of simple expansion; the fundamental rights and principles are supposed to have remained essentially unchanged after being enshrined in the basic institutions and constitutions of our democratic societies, although they have steadily expanded (and have been applied to new social groups or new circumstances). However, the French sociologist, Marcel Gauchet points out that this interpretation is too straightforward: granting certain rights to new groups in society - even without literally redefining those rights changes the nature of our democracy. For instance, expanding the right to vote, rather than removing antagonisms from the political agenda, is likely to provoke a reorganisation of the agenda by permitting the legitimate expression of racial, cultural, social or other antagonisms that were not recognized before. Moreover, the previously existing democratic institutional arrangement and the previously prevailing interpretation of constitutional principles are redefined in retrospect as excluding the expression of the legitimate concerns that inspired these antagonisms in the first place. ${ }^{35}$

Thirdly, if we give up the idea that an agreement regarding the basic structure and constitutional principles is underlying our everyday political conflicts, the general idea of sanctioning the exercise of power by referring to a consensus (whether first or second-order) not only becomes unfeasible; it also becomes, from a democratic point of view, much less desirable. The problem is in the first instance not that such a consensus may be nonexistent, that the social fact of "deep disagreement" challenges the very idea that deliberation could provide a source of political justification. ${ }^{36}$ The fundamental problem is that situations may always occur (as they have done in the past) in which allegiance to democratic ideals and values demands that citizens question and go beyond the existing consensus. ${ }^{37}$ This is not merely a consequence of the undeniable fact that the existing situation - the 
common practices and opinions of politics or law - do not always conform to the principles of a democratic regime. Given that the very interpretation of democratic principles is an issue in everyday politics, the opinions with regards to the requirements of democracy in general or in the particular situation in which citizens find themselves at a certain point in history, may change.

If something like Rawls' overlapping consensus were ever to arise, it would be vulnerable at any moment, because citizens refuse to accept limits to public discussion as proposed by Rawls and insist on discussing all matters of political importance freely with every other citizen. They do so, moreover, with good reason. Yet at the same time, they have no reason to expect that such discussions will or will always lead to reasonable consensus, as Habermas believes. In this sense the exercise of power cannot derive any stable justification from a consensus among the citizens.

To conclude, a common interpretation of the relationship between basic principles on the one hand and everyday politics on the other, must be reconsidered. If we concede the fact that routine political conflicts and decisions may also involve the institutional arrangement of society and its most fundamental principles or norms, it is less plausible to conceive of this relationship as that between the general and the specific; as though there were general agreement on basic principles and that further specification in the context of actual decision-making is delegated to those in power. As a result, it is even less feasible to refer to a second-order consensus on these fundamental issues (assuming such a thing exists), in order to explain the reasonableness of those imposing decisions in response to everyday conflicts.

\section{Power and public discussion}

An alternative interpretation of political reasonableness suggests itself, if we consider the following two points. Firstly, both Rawls and Habermas assume that the significance of public argumentation and discussion, politically speaking, is that it will ultimately lead to consensus, to a common opinion or will. This assumption is obvious in the case of Habermas, but a parallel conception of the significance of public argumentation and discussion is also assumed by Rawls. Rawls imposes limitations on public discussion because he (correctly) suspects that such discussions will not lead to consensus. This shows that Rawls expects nothing else from public discussion and argumentation. However, in contrast to this view of public discussion, we must acknowledge that what is shared in the public sphere of a democratic society is not - or not primarily - the product of deliberation, that is to say, a shared conclusion. What is shared is the process of deliberation, the very existence of a public sphere: the fact that citizens who are geographically dispersed nonetheless deliberate with each other and 
speak out about the exercise of power. ${ }^{38}$ As a matter of fact, the role of argumentation and discussion in a democracy appears to be more paradoxical than the straightforward accounts of Habermas and Rawls allow. On the one hand, public argumentation is argumentation in a true sense: it is a complex of speech acts with which we try to convince a listener; however, on the other hand, the political significance of public argumentation and discussion cannot be reduced to that of a process leading to consensus. Indeed it often does not.

Secondly, in an article discussing Rawls' overlapping consensus, Jean Hampton has pointed out that Thomas Hobbes developed an alternative solution to the problem of social unity and stability: "It would be, in (Hobbes') eyes, a hopeless task to try to find any significant overlap of views in pluralist societies such as ours... . Stability...is something that we pursue via polity and not via consensus on ideas. Only a ruler with the power to have the last word is able to forestall conflict." 39 To the extent that the reasonable exercise of power - in either the purely consensual or the second order interpretation - is ideally sanctioned by the consensus of the citizens, those in power are simply not independent enough to have the last word.

These two remarks are evidently connected: if we expect public discussion among citizens to produce a common opinion or will (contrary to the first remark), we do not need independent rulers who 'have the last word' (contrary to the second remark). In order to understand the reasonableness of power in a democracy, we must acknowledge that, even in a democracy, political power is in a real sense autonomous. However great the differences may be between rational choice theory and deliberative democracy, the conclusion of this discussion is analogous to the solution of a prisoner's dilemma: in both cases, we discover that power is unavoidable; we discover that we need 'rulers'; we need people who have enough power and enough autonomy to impose a decision. Consequently, we must accept that even in a democracy one or more groups may get beaten, that often decisions are imposed against the citizens' will and that these decisions will have a profound effect on their lives, sometimes affecting even the very survival of vulnerable members of society. ${ }^{40}$ In other words, we must accept that democratic politics is just another manifestation of the struggle for power; one fought according to its own rules. Those with ambitions of government, however lofty their intentions, must accept the rules of the game.

In order to understand the reasonableness that political power may acquire in a democracy we must acknowledge that the political significance of public argumentation and discussion cannot be reduced to the mere means to a consensus and that we may therefore need an independent political authority to "have the last word". How must we then conceive of the relationship between this independent exercise of power and public argumentation and discussion, so that we may say that the former derives some reasonableness from the latter? 
In a democracy, the rules of the political game compel those struggling for power to regularly submit to the decision of the voters. At election time, the citizen subject to political power ideally acts as a powerbroker, apportioning power. (The power of citizens cannot, of course, be reduced to the power they derive from their role as voters; however an exact analysis of citizens' power is not necessary for the purposes of this essay.) As Hannah Arendt put it in the quotation with which we began "the people are supposed to rule those who govern them". To understand the role of political reason in this game of power, however, we must not overlook the fact that a citizen not only holds power as a voter, but also has the right to speak, and perhaps more importantly, to listen in the public sphere.

Because of that double role, politicians struggling for power in a democracy cannot disregard the opinions that are being formed in the public sphere. Moreover, given that a kind of continuity exists between our opinions concerning actual decisions imposed on us by those in power and, in turn, our opinions with regard to their legitimacy, the democratic exercise of power not only requires the citizens' general approval of the government but also the approval of at least some citizens with at least some (or perhaps even a majority of) the government's decisions. Accordingly, Habermas' adaptation of Arendt's 'communicative power' is very useful in expressing the fact that the rules of the struggle for power in a democracy ensure that those in power cannot ignore opinions that gain acceptance in the public sphere. My suggestion is therefore that we will understand how political power acquires a certain form of reasonableness in a democracy, if we develop a correct understanding of this notion of communicative power.

Three remarks are in order. Firstly, although I am happy to appropriate the expression 'communicative power', I do not want to use this expression with the rather idealized meaning it has in the work of Habermas (and Arendt). Communicative power is, in my view, not the privilege of the one common opinion upon which the citizens all agree. Moreover, I do not imagine that the public sphere, in which communicative power is generated, is in some sense exceptionally reasonable and free from relations of power. It is the rules of the power game that force politicians to get involved in what happens in the public sphere. We know what it is that they want: even in the public sphere they want power and obedience. Other citizens may not directly strive for political power, but they seek fame, prestige or influence, or the promotion of their own interests. We cannot presuppose that speakers in the public sphere all intend to participate in 'a cooperative search for truth', to use another of Habermas' terms. Consequently, we may also allow strategic considerations to guide our behavior in the public sphere. Communicative power as I would like to use the expression, is a purely rhetorical concept. It is a function of the support that an opinion receives in the beliefs of the citizens. However, this does not imply anything 
about the wisdom of the opinion or the fairness of the process in which the opinion has gained that support.

Secondly, communicative power is an attribute of opinions or beliefs that are formed, confronted and judged in the public sphere. Although public argumentation and discussion in the public sphere is not imagined to be fair or equal, to the extent that it involves a process in which opinions or beliefs are formed, it nonetheless displays a certain reasonableness. For instance, it does exclude violence, coercion and bribery. The fact of the matter is that we may be able to force or bribe someone to say whatever we like, but we cannot make him believe it. Violence, coercion and bribery are in principle excluded from the public sphere because of the fact that any speaker, however unscrupulous, has to compete for the opinion of the citizens. ${ }^{41}$

Thirdly, according to 'the ideal of consensus' mentioned above, opinions or beliefs imply the claim that they are based on sufficiently good arguments - they presuppose a claim to validity, as Habermas would put it. Of course, some beliefs are false, but there is a conceptual link between believing a proposition and the truth of a proposition, in the sense that it is impossible to believe that $p$, while consciously acknowledging that $p$ is not true. ${ }^{42}$ Consequently, the only notion of rationality appropriate to beliefs is an 'epistemic' form of rationality. Moreover, it follows that we cannot rationally entertain the actual existence of decisive reasons for not believing that $p$ while still continuing to believe that $p$. This means that if we believe that $p$, we seem rationally committed to the belief that there are no convincing arguments against $p$.

Opinions or beliefs are therefore by definition vulnerable and temporary: as soon as we realize that there are convincing objections to one of our beliefs or to the arguments used to justify it, we feel we should give it up. In this (considerably less idealized) sense, we might even say that a search for truth takes place in the public sphere.

In a democracy, administrative power (political power in the narrow sense) and communicative power (as an attribute of opinions that are vulnerable to objections) appear to be complementary. On the one hand, democratic government requires that those holding administrative power have sufficient autonomy to "have the last word", to cut short discussion in the public sphere by imposing a decision. On the other hand, this autonomous political power, even if it can sometimes go against the opinion of the majority, eventually languishes without the support of public opinion. As a result, opinions acquire communicative power.

From this complementary relationship, political power in a democracy derives a particular reasonableness. If citizens agree with the decision imposed, the exercise of power appears to them to be reasonable: that is, a way of putting into practice or turning into law what they believe to be right (fair, appropriate, necessary, timely, etc.). If citizens do not agree, they may nonetheless have good (strategic) reasons to submit to the decision; they 
may want to avoid punishment and they may be aware that public argumentation and discussion in the public sphere will not lead - in the time available - to a common opinion (and that the particular decision in question, or even any decision, is preferable to continuing indecision, an escalating conflict or the breakdown of the democratic order).

In contrast to the so-called two-order interpretation, however, the particular content of the decision is not excluded from consideration. As a matter of fact, citizens know that those in power are dependent on the communicative power acquired by opinions in the public sphere - opinions that refer to particular decisions and are linked to claims to validity. Accordingly, even citizens who believe that the decision is wrong and that its claim to validity is not justified, are aware that the power enforcing this 'wrong' decision is ultimately derivative, to some degree, from opinions associated with certain validity claims (for instance, with the claim that this particular decision is fair, appropriate, necessary, timely, etc.). Anything associated with such validity claims, however, becomes vulnerable to objections. Imposing a decision is therefore never the end of the matter; the power with which the decision is imposed depends on opinions about which public debate may be reopened at any moment. Ideally, there will always be new opportunities to convince other citizens to withdraw their support for the decision. If the opponents convince enough of their fellow citizens, they may succeed in eroding the communicative power supporting the decision and may even rally enough support to have the decision amended or overturned. By formulating convincing objections to opinions circulating in the public sphere, we alter the balance of communicative power, so to speak. When submitting to the decision, citizens are aware of these aspects of democratic politics. (There is no denying, of course, that amendments may come too late for those who have suffered the consequences of earlier decisions.)

To the extent that those holding administrative power are dependent on communicative power, citizens may influence the former by discussing and criticizing opinions in the public sphere. In this sense, we may say that democracy serves to establish a particular balance of power between administrative and communicative power and between the communicative power of different opinions circulating in the public sphere - a balance of power that confers a certain reasonableness to the exercise of administrative power. This reasonableness does not derive from a consensus among citizens, but from its association with opinions open to objections. Our attitude towards the exercise of power is therefore not wholly determined by strategic considerations; given that political power in a democracy is dependent on communicative power generated by discussing opinions in the public sphere, democratic power is directed towards the consent of the citizens. It involves them in public discussion and appeals not solely to their strategic but also to their epistemic rationality. 
While this paper was written with representative democracy in mind, neglecting the possible differences between representative and direct forms of democracy, the balance of power described above is arguably (if not more markedly) present in forms of direct democracy as well. Even in a direct democracy, discussion and argumentation cannot go on indefinitely and must therefore be cut short by a majority decision; that is to say, by an exercise of power that is not sanctioned by a general consensus among participants. However, it is obvious that majority rule is dependent on the opinion of those constituting the majority. As an exercise of power, a majority decision is therefore linked to opinions, which presuppose validity claims and, as a result, acquires a vulnerability to objections that, as I have argued, bestows it with a certain reasonableness.

Metaphorically speaking, we may say that political power in a democracy is reasonable to the extent that it adopts the vulnerability or fragility of opinion. What is demanded of reasonable citizens is therefore not that they accept certain limits of public argument and discussion, nor that they are willing to subject all their opinions to thorough criticism in a so-called rational discussion. What is demanded of reasonable citizens is that they have sufficient confidence in the process of public argumentation and discussion and in the communicative power that opinions may gain in the public sphere. This confidence is expressed by participating in the discussions taking place in the public sphere (if only as a listener) and by perceiving the public sphere in its true light. For the public sphere is at once an arena permeated with power, in which we fight for our interests and beliefs, and a forum, in which we try to find out what to believe. It is thus a social sphere that simultaneously appeals to our strategic and epistemic rationality. This confidence in the public sphere forms the basis of our willingness to grant a certain amount of autonomy to those exercising power. ${ }^{43}$

\section{Notes}

1. Arendt $(1986,62)$

2. Rawls (1996, xlv).

3. Rawls (1996, 136, 38).

4. Elster (1986); Habermas (1992, 405)=Habermas (1996a, 334); Blaug (1996, 50-51); Bohman and Rehg (1997, X, XIII); Bohman (1998, 401); Dryzek (2000, 10-12); Freeman (2000, 374-375).

5. Elster $(1986,105)$.

6. I will also assume (what I have no reason to doubt anyway) that most human beings and a fortiori most citizens of a democratic society "are deeply concerned with matters of...justice and with an accurate understanding of these matters". The causes of conflict and disagreement in political society cannot be reduced therefore to incompatible interests; conflict and disagreement "are often generated by pervasive and sincerely based disagreement" on matters of justice, cf. Christiano (1997, 261).

7. See also Manin, Przeworski et al. $(1999,6)$.

8. Rawls (1996, 36, cf. 54). 
9. See for instance, Rawls $(1996,136,222)$.

10. I will also ignore the fact that Rawls allows for the possibility that the consensus does not focus on one political conception but rather on a family of reasonable political conceptions.

11. Rawls (1996, 147); Rawls (1987, 422); cf also Larmore (1996b, 121, 145).

12. Rawls (1996 657, 387, my emphasis, cf. 384, 386, 38, 529). This is what Rawls means when he stipulates that a political conception of justice must be 'freestanding': "justice as fairness is to be understood at the first stage of its exposition as a freestanding view that expresses a political conception of justice. It does not provide a specific religious, metaphysical, or epistemological doctrine beyond what is implied by the political conception itself...The political conception is a module...that in different ways fits into and can be supported by various reasonable comprehensive doctrines...", Ibid., 144-145 (See XLIV).

13. Rawls (1996, 387, cf. 375).

14. Habermas $(1996 b, 78)=$ Habermas (1996c, 99). See also Scheffler $(1994,13,16-17)$. McCarthy (1994, 53), Baynes (1992, 55), Gutmann (1995, 102-103); Gray (1995, 125-126).

15. Rawls does not deny the fact, but he denies that it is relevant for political philosophy: "all discussions are from the point of view of citizens in the culture of civil society, which Habermas calls the public sphere. There, we as citizens discuss how justice as fairness is to be formulated, and whether this or that aspect of it seems acceptable ... It is the culture of the social, not of the publicly political" Rawls (1996, 382-383, see also 214 215). It is not clear to me how we must view these discussions "in the culture of civil society": are they discussions between supporters of the same comprehensive doctrines (inside the associations that are dependent on a particular doctrine) or are they fundamental discussions between supporters of different doctrines in which we also discuss the arguments that supporters of doctrines different from our own put forward in support of the political conception of justice?

16. Skorupski (1996, 110); Skorupski (1985-1986); Cf. Habermas (1996c, 108); Habermas $(1981,417-418)=$ Habermas $(1984,397-399)$. This general epistemological principle applies especially to the case of moral judgments and arguments, since we are apt to accept that the force of moral judgments and arguments are not relative to any personal perspective.

17. Rawls (1996, xlvi, 81).

18. This is not just the claim that excluding someone from deliberation concerning a decision that will affect his life shows lack of respect. It is the stronger claim that respect for a person may demand our criticizing his views, see Burms (1990)

19. Habermas (1996c, 105)=Habermas (1996b, 83): "Observers can describe what happens in the political realm, for example, that an overlapping consensus has occurred...But in the objectifying attitude of observers citizens cannot penetrate each others' worldviews and judge their truth content from the internal perspective peculiar to each... They cannot take a stand on what committed participants claim to be true, right, and valuable from their first person perspectives".

20. In some passages (as when he describes the powers of the citizen and the sort of objectivity claimed by his political constructivism, for example, Rawls $(1996,119,49))$ Rawls seems to support an epistemological interpretation of consensus and of reasonableness, according to which the fact that an agreement is reached about a conception of justice after discussion under certain (ideal) conditions is an indication that this conception is morally right, that it truly contains principles of a just society. Aspiring to resolve as a political philosopher the problem of social unity and stability and to be able to offer a viable conception of justice that can be endorsed by his fellow citizens as part of an overlapping consensus, however, Rawls ultimately substitutes this epistemological interpretation of consensus and reasonableness for an interpretation in 
which 'reasonable' acquires the meaning of 'pragmatically expedient'. From that perspective, the value of consensus is reduced to its practical value in promoting stability and in making living together easier. Rawls' pragmatic attitude is especially obvious when he explains the attitude with which he submits his own liberal conception of justice ('justice as fairness'): "Let us suppose that we...succeed in reaching an overlapping consensus on a conception of political justice. It will then be...reasonable. Some might insist that reaching this reflective agreement is sufficient grounds for regarding that conception as true...But we refrain from this further step: it is unnecessary and may interfere with the practical aim of finding an agreed public basis of justification", Rawls (1996 153, cf. XXI-XXII, LVI, 94, 116, 123-126); See also, for instance, Rawls (1999c, 395).

21. See for instance Habermas $(1992,138-139)=$ Habermas $(1996 a, 108)$.

22. See for example Rorty (1991b, 175-176) and also Rorty (1991a) and Visker (1992).

23. Rawls (1996, li, 240-241). Cf. McCarthy (1994, 55); Baynes (1992, 57-62); Larmore (1996a, 214-215).

24. Rawls (1996, 136, xxvi-xxvii, cf. also 39, 135); Rawls (1999a, 673).

25. I am grateful to Wilfried Goossens for pointing this out to me.

26. For example, Joshua Cohen seems inclined to share Habermas' confidence: Habermas even criticizes Cohen for being too optimistic concerning the possibilities of argumentation and discussion in complex societies such as ours, Habermas (1992, 369-370) $=$ Habermas (1996a, 304-305). Authors such as Bohman (1996), Gutmann and Thompson (1999, 278-279), Fishkin (1986; Fishkin (1991), Gaus (1997; 1999), Christiano (1997) are increasingly sceptical about the possibility and even the value of consensus. Ackerman (1989) wants to impose even stricter limitations on public argumentation and discussion. John Dryzek seems to adopt a middle position: he does place his hopes, echoing a phrase of Habermas, in "the forceless force of better communication", but declares himself satisfied with what is in effect Rawls' overlapping consensus: "citizens agreeing for different reasons", see for example Dryzek $(2000,172)$.

27. Rawls (1999b, 578); see also Larmore (1999, 600). Surprisingly, this very same idea may also be read in the work of authors who are very critical of both Rawls and Habermas, see for example MacIntyre (1985, 11); Taylor (1995, 308-309).

28. To acknowledge this fact seems, at any rate, to be the point of the distinction Rawls makes between the legitimacy of decisions and laws and their justice, see for instance Rawls (1996, 427-429). Habermas also repeatedly emphasizes that our contemporary society is too complex to be organized and governed solely through deliberation and argumentation, see Habermas (1992, 369-370, 389, 434)=Habermas (1996a, 305-304, 320 ). Even on a strictly political level, political bargaining, compromises and majority decisions are unavoidable, Habermas $(1992,139,221,344)=$ Habermas $(1996 a, 108,179$ 180, 282-283). See also Rawls (1999b, 605-606).

29. See for instance Rawls (1996, 10-11, 293, 284): "Thus even in a well-ordered society, adjustments in the basic structure are always necessary. And so an institutional division of labor must be established between the basic structures and the rules applying to particular transactions. Individuals and associations are left free to advance their ends within the framework of background institutions which carry out the operations required to maintain basic justice", see also Rawls (1996, 10-11, 293).

30. See for example, Habermas $(1992,137)=$ Habermas (1996a, 68); See also, Bohman (1996), Gutmann and Thompson (1999, 255-256).

31. Gaus $(1997,233)$.

32. Gaus $(1997,236)$ suggests that doubting the justifiability of the umpire is an antidemocratic attitude, tantamount to wanting to overturn democracy. But this would make adjudication by an umpiring mechanism virtually synonymous with democracy. Surely, this is overstated: a constitutional court, for instance, bases, I assume, its rulings 
on the existing constitution, so it cannot act as an impartial umpiring body in a dispute between citizens about (a proposal to add to or change) the constitution itself. And the same thought applies to disputes about the competence or the role of the constitutional court itself. Moreover, as I will explain below, our judgment concerning the impartiality of the umpire is not independent of our views on the actual rulings of the umpire. If the umpire consistently rules against certain causes or interests it is only to be expected that its impartiality will be doubted by supporters of these causes or interests. We should not overlook the fact that the very nature of democracy or of reasonableness may be a matter of contention.

33. Arendt (1970, $41-2)$.

34. Mansbridge (1997, 408-415).

35. Gauchet $(1994,103)$.

36. In order to argue that the emergence of a consensus is not implausible, Rawls and Habermas correctly point out that citizens of countries that developed democratic institutions over a long history are raised in a democratic culture - in what Rawls calls 'a public political culture', see for instance, Rawls (1996, 13-14); and Habermas describes as 'a life-world that meets deliberative politics halfway'. Habermas (1992, $89)=$ Habermas (1996a, 65). Consequently, "we can presume", in the words of Rawls, "not only some public understanding but also some allegiance to democratic ideals and values as realized in existing political institutions".

37. A comparable objection is made by Gaus (1997; Gaus (1999), who argues that consensus among citizens is only of relative value, considering the fact that the reasonableness of our fellow-citizens leaves something to be desired, cf. also Estlund (1997, 178).

38. cf. Taylor (1995, 261-263).

39. Hampton (1989, 800-801); cf. also Gauthier (1995).

40. See for instance, Mansbridge (1994; Mansbridge (1997).

41. For the conception of argumentation and discussion on which this and the following paragraph are based, see Heysse (1998).

42. This is a version of what has been called 'Moore's paradox', see Baldwin (1990, pp. 226 32); Moore (1959, p. 175); See also Williams (1973, p. 145, 136).

43. Earlier versions of this paper were read at the $4^{\text {th }}$ European Conference of Analytical Philosophy organized in Lund, Sweden, at the $5^{\text {th }}$ International Conference on Argumentation in Amsterdam, at a workshop on the political philosophy of John Rawls organized by Ronald Tinnevelt and Robert van de Veen in Dordrecht, the Netherlands and at the Séminaire de philosophie politique et sociale directed by Philippe Van Parijs at the Université Catholique de Louvain. Most of the work on it was made possible by a grant from the Fund for Scientific Research - Flanders (Belgium). Since the original version was written as my contribution to the work done by the Onderzoeksgroep Politieke Filosofie (the Study Group for Political Philosophy) of the K.U. Brussel, it owes much to the other participants of the group at that time: Peter De Graeve, Jan Frans Lindemans, Katia Vanhemelryck, and, first and foremost - as always - to Wilfried Goossens. For those familiar with the work of Claude Lefort my debt to its inspiration will be obvious. If this essay at least gives the impression of being written in English, this is due to the efforts of Jeremy McKenna.

\section{References}

Ackerman, B. (1989) "Why dialogue?", The Journal of Philosophy, LXXVI(1), pp. 5-22.

Arendt, H. (1970) On Violence (New York: Harcourt, Brace \& World, Inc).

Arendt, H. (1986) "Communicative Power", in Power, S. Lukes (Ed.) (Oxford: Basil Blackwell). pp. $59-74$.

Baldwin, T. (1990) G.E. Moore (London/New York: Routledge). 
Baynes, K. (1992) "Liberal neutrality, pluralism, and deliberative politics", Praxis International, 12(1), pp. 50-69.

Blaug, R. (1996) "New theories of discursive democracy: a user's guide", Philosophy \& Social Criticism, 22(1), pp. 49-80.

Bohman, J. (1996) Public Deliberation: Pluralism, Complexity, and Democracy (Cambridge, Massachusetts/London: The MIT Press).

Bohman, J. (1998) "The coming of age of deliberative democracy", Journal of Political Philosophy, 6(4), pp. 400-425.

Bohman, J. \& Rehg, W. (1997) "Introduction", in Deliberative Democracy: Essays on Reason and Politics, J. Bohman \& W. Rehg (Eds) (Cambridge, Massachusetts/London: The MIT Press). pp. IX-XXX.

Burms, A. (1990) "Helping and Appreciating", in What Right does Ethics Have? Public Philosophy in a Pluralistic Culture, S. Griffioen (Ed.) (Amsterdam: V.U. University Press). pp. 67-77.

Christiano, T. (1997) "The Significance of Public Deliberation", in Deliberative Democracy: Essays on Reason and Politics, J. Bohman \& W. Rehg (Eds) (Cambridge, Massachusetts/ London: The MIT Press). pp. 243-277.

Dryzek, J. S. (2000) Deliberative Democracy and Beyond: Liberals, Critics, Contestations (Oxford: Oxford University Press).

Elster, J. (1986) "The Market and the Forum: Three Varieties of Political Theory", in Foundations of Social Choice Theory, A. Hylland (Ed.) (Cambridge: Cambridge University Press).

Estlund, D. (1997) "Beyond Fairness and Deliberation: The Epistemic Dimension of Democratic Authority", in Deliberative Democracy: Essays on Reason and Politics, J. Bohman \& W. Rehg (Eds) (Cambridge, Massachusetts/London: The MIT Press). pp. 173-204.

Fishkin, J. S. (1986) "Liberal Theory and the Problem of Justification", in Justification, J. R. Pennock \& J. W. Chapman (Eds) (New York: New York University Press). pp. 207-231.

Fishkin, J. S. (1991) Democracy and Deliberations: Directions for Democratic Reform (New Haven and London: Yale University Press).

Freeman, S. (2000) "Deliberative democracy: a sympathetic comment", Philosophy \& Public Affairs, 29(4), pp. 371-418.

Gauchet, M. (1994) “Tocqueville” (1980), in New French Thought. Political Philosophy, M. Lilla (Ed.) (Princeton, N.J.: Princeton University Press). pp. 91-111.

Gaus, G. F. (1997) "Reason, Justification, and Consensus, Why Democracy Can't Have It All”, in Deliberative Democracy: Essays on Reason and Politics, J. Bohman \& W. Rehg (Eds) (Cambridge, Massachusetts/London: The MIT Press). pp. 205-242.

Gaus, G. F. (1999) "Reasonable pluralism and the domain of the political: how the weaknesses of John Rawls's political liberalism can be overcome by a justificatory liberalism", Inquiry, 42(2), pp. 259-284.

Gauthier, D. (1995) "Public reason”, Social Philosophy and Policy, 12(1), pp. 19-42.

Gray, J. (1995) "Agonistic liberalism”, Social Philosophy and Policy, 12(1), pp. 111-135.

Gutmann, A. (1995) "Moral disagreement in a democracy", Social Philosophy and Policy, 12(1), pp. $87-110$.

Gutmann, A. \& Thompson, D. (1999) "Disagreeing about Deliberative Democracy: Reply to the Critics", in Deliberative Politics: Essays on Democracy and Disagreement, S. Macedo (Ed.) (New York: Oxford University Press). pp. 243-279.

Habermas, J. (1981) Theorie des kommunikativen Handelns. Handlungsrationalität und gesellschaftliche rationalisierung (Frankfurt am Main, Suhrkamp Verlag).

Habermas, J. (1984) The Theory of Communicative Action: Reason and the Rationalization of Society (Boston: Beacon Press). 
Habermas, J. (1992) Faktizität und Geltung. Beiträge zur Diskurstheorie des Rechts und des demokratischen Rechtsstaats (Frankfurt am Main, Suhrkamp Verlag).

Habermas, J. (1996a) Between Facts and Norms: Contributions to a Discourse Theory of Law and Democracy (Cambridge: Polity Press).

Habermas, J. (1996b) "'Reasonable' versus 'True', or the Morality of Worldviews", in The Inclusion of the Other: Studies in Political Theory by Jürgen Habermas, C. Cronin \& P. D. Greiff (Eds) (Cambridge: Polity Press). pp. 75-101.

Habermas, J. (1996c) “"Vernünftig' versus 'wahr' - oder die Moral der Weltbilder”, Die Einbeziehung des Anderen. Studien zur politischen Theorie (Frankfurt am Main, Suhrkamp Verlag), pp. 95-128.

Hampton, J. (1989) 'Should political philosophy be done without metaphysics?", Ethics, 99, pp. 791-814.

Heysse, T. (1998) "Transcendence, truth, and argumentation", Inquiry, 41(4), pp. 411-434.

Larmore, C. (1996a) "The Foundations of Modern Democracy. Reflections on Jürgen Habermas", in The Morals of Modernity (Cambridge, New York, Melbourne: Cambridge University Press). pp. 205-221.

Larmore, C. (1996b) "Political Liberalism", in The Morals of Modernity (Cambridge, New York, Melbourne: Cambridge University Press). pp. 121-151.

Larmore, C. (1999) "The moral basis of political liberalism", The Journal of Philosophy, XCVI(12), pp. 599-625.

MacIntyre, A. (1985) "Relativism, power and philosophy", Proceedings and Addresses of the American Philosophical Association, 59(1), pp. 5-22.

Manin, B. \& Przeworski, A., et al. (1999) "Introduction", in Democracy, Accountability, and Representation, A. Przeworski, S. C. Stokes \& B. Manin (Eds) (Cambridge: Cambridge University Press). pp. 1-26.

Mansbridge, J. (1994) "Using power/fighting power", Constellations, 1(1), pp. 53-73.

Mansbridge, J. (1997) "Taking coercion seriously", Constellations, 3(3), pp. 407-416.

McCarthy, T. (1994) "Kantian constructivism and reconstructivism: Rawls and Habermas in dialogue", Ethics, 105(4), pp. 44-63.

Moore, G. E. (1959) "Russell's Theory of Descriptions" (1949), in Philosophical Papers, (London/New York: Allen and Unwin).

Rawls, J. (1987) "The idea of an overlapping consensus", Oxford Journal of Legal Studies, 7(1), pp. $1-25$.

Rawls, J. (1996) Political Liberalism. With a New Introduction and the "Reply to Habermas" (New York: Columbia University Press).

Rawls, J. (1999a) Collected Papers. Samuel Freeman (Ed.) (Cambridge, Massachusetts/London, England: Harvard University Press).

Rawls, J. (1999b) "The Idea of Public Reason Revisited" (1997), in Collected Papers, Samuel Freeman (Ed.) (Cambridge, Massachusetts/London, England: Harvard University Press). pp. 573-615.

Rawls, J. (1999c) "Justice as Fairness: Political not Metaphysical" (1985), in Collected Papers, Samuel Freeman (Ed.) (Cambridge, Massachusetts/London, England: Harvard University Press). pp. 388-414.

Rorty, R. (1991a) "Habermas and Lyotard on Postmodernity" (1984), in Essays on Heidegger and Others. Philosophical Papers, Volume II (Cambridge: Cambridge University Press). pp. 164-176.

Rorty, R. (1991b) "The Priority of Democracy to Philosophy" (1988), in Objectivity, Relativism, and Truth: Philosophical Papers (Cambridge: Cambridge University Press). pp. 175-196.

Scheffler, S. (1994) "The appeal of political liberalism", Ethics, 105(4), pp. 4-22.

Skorupski, J. (1985-1986) "Objectivity and convergence", Proceedings of the Aristotelian Society. New Series, LXXXVI, pp. 235-250. 
Skorupski, J. (1996) "Value Pluralism", in Philosophy and Pluralism. Royal Institute of Philosophy. Supplement 40, D. Archard (Ed.) (Cambridge: Cambridge University Press). pp. 101-115.

Taylor, C. (1995) "Liberal Politics and the Public Sphere", in Philosophical Arguments, (Cambridge, Massachusetts/London, England: Harvard University Press), pp. 257-287, 308-309.

Visker, R. (1992) "Habermas on Heidegger and Foucault: meaning and validity in the philosophical discourse of modernity", Radical Philosophy, 61(Summer), pp. 15-22.

Williams, B. (1973) "Deciding to Believe" (1970), in Problems of the Self: Philosophical Papers 1956-1972 (Cambridge: Cambridge University Press). pp. 136-151. 